\title{
Management of the polytrauma patient with pelvic fracture
}

\author{
Abordarea pacientului politraumatizat cu fractură de bazin \\ Dumitru COSTIN ${ }^{1,2}$, Iulia-loana STĂNESCU ${ }^{3}$, Alexandra TOTAN², Daniela MIRICESCU², \\ Iulian Constantin CREANGĂ ${ }^{2,4}$, Maria GREABU² \\ ${ }^{1}$ Spitalul Clinic de Urgență, Bucureşti, România \\ ${ }^{2}$ Disciplina Biochimie, Facultatea de Medicină Dentară, \\ Universitatea de Medicină şi Farmacie „Carol Davila”, Bucureşti, România \\ ${ }^{3}$ Disciplina Fiziologie, Facultatea de Medicină Dentară, \\ Universitatea de Medicină şi Farmacie „Carol Davila”, Bucureşti, România \\ ${ }^{4}$ Spitalul de Urgență M.A.I. „Prof. Dr. Gerota“, Bucureşti, România
}

\section{ABSTRACT}

High energy trauma has become a part of everyday life, therefore the thorough study of the biochemical impact of polytrauma on the human body is also a priority. In the initial post-traumatic phase, tissue trauma produces a local and general inflammatory response (SIRS). Pelvic ring fractures are relatively rare lesions, with a reported incidence of about 2-8\% of all fractures, but in polytrauma patients, the incidence may increase to over $25 \%$. The hemorrhagic risk makes the fractures of the pelvic ring one of the most serious injuries of the musculoskeletal system with a reported mortality between 5 and $50 \%$. The priority of the initial treatment is identification and treatment of lesions that endanger the patient's life, the objective of definitive stabilization being the correction of the deformity, function restoration and decrease of the complication rate.
\end{abstract}

Keywords: trauma, pelvic fracture, polytrauma pacient

\section{REZUMAT}

Traumatismele de energie înaltă au devenit parte a cotidianului, studiul aprofundat al impactului biochimic al politraumatismului asupra corpului uman devenind o prioritate. În faza inițială posttraumatică, agresiunea asupra țesuturilor produce un răspuns inflamator local şi general (SIRS). Fracturile de inel pelvin sunt leziuni relativ rare, cu o incidență raportată de aproximativ 2-8\% din totalul fracturilor, dar la pacienții politraumatizați această incidență poate creşte până la peste $25 \%$. Riscul hemoragic face din fracturile de bazin una dintre cele mai serioase leziuni ale aparatului locomotor, având o mortalitate raportată ca fiind între 5 şi 50\%. Prioritățile tratamentului inițial sunt identificarea şi tratamentul leziunilor ce pun în pericol viața pacientului, obiectivul stabilizării definitive fiind corectarea diformității, restaurarea funcției şi reducerea ratei complicațiilor.

Keywords: traumatism, fractură de bazin, pacient politraumatizat 


\section{INTRODUCERE}

În realitatea contemporană, „epoca vitezei“, cum a fost denumită, traumatismele de energie înaltă au devenit parte a cotidianului, motiv pentru care studiul aprofundat al impactului biochimic al politraumatismului asupra corpului uman a devenit o prioritate în ultima perioadă, fiind acoperită de cercetări extinse.

În faza inițială posttraumatică, agresiunea asupra țesuturilor produce un răspuns inflamator local și general (SIRS) caracterizat de eliberarea de danger-associated-molecular-patterns (DAMPs) care pot produce un răspuns inflamator și imunologic rapid [1].

Mediatori și elemente celulare conlucrează pentru restaurarea homeostaziei organismului după traumatism, principalul reglator fiind citokinele. Interleukina-6 (IL-6), eliberată ca răspuns la injuria tisulară, are efecte locale și generale cu scopul de a readuce organismul la condițiile fiziologice. Valorile IL-6 cresc în traumatism cu apariția sindromului inflamator, acest proces fiind urmat în mod normal de un răspuns antiinflamator, care în general este mediat de IL-10 (interleukina-10), una dintre cele mai importante citokine antiinflmatorii [2].

Valori ridicate ale citokinelor TNF- $\alpha$, IL-1 $\beta$ sau IL-8 au fost observate la pacienții cu sindrom inflamator sistemic, iar valoarea IL-6 a fost corelată cu Injury Severity Score (ISS, incidența insuficienței multiple de organ - MODS), sepsis și prognosticul vital [3]. IL-6 are, de asemenea, și proprietăți antiinflamatorii, atât prin inducerea eliberării de prostaglandină E2, cât și prin promovarea eliberării antagoniștilor receptorilor de IL-1 $\beta$ și TNF- $\alpha$ [4].

Citokinele sunt glicoproteine cu masa moleculară mică implicate în răspunsul imun în inflamație, traumatism și vindecare. Ele își exercită efectul la nivel autocrin, paracrin și endocrin. Citokinele, ca mediatori intercelulari, se leagă de receptori specifici de la nivelul membranei celulare a celulelor țintă și pot produce alterarea sintezei proteice [5]. Această alterare a sintezei proteice poate duce la creșterea secreției de citokine, întreținând practic procesul inflamator.

Date din studii experimentale și clinice au demonstrat în mod repetat că acest proces dinamic este influențat suplimentar de o serie de alți parametri, incluzând aici activarea indusă de traumatism a sistemului neuro-endocrin și ulterior schimbări în microcirculație, cascada coagulării și diverse secvențe metabolice. Acestea, nu numai că se interconectează la nivelul răspunsului imun înnăscut, dar sunt capabile, independent, să afecteze critic profilul inflamator predominant și progresia consecutivă a bolii. Influența imunologică pare să fie dată de o polarizare a acestuia de către celulele T-helper-1 (Th1), proinflamatorii în defavoarea fenotipului Th2 cu rol antiinflamator. Interacțiunea dintre celulele imune și eliberarea de citokine sunt grav afectate, fiind urmate de o imunoparalizie, considerată a fi una dintre principalele cauze ale apariției complicațiilor posttraumatice [6].

\section{PACIENTUL POLITRAUMATIZAT CU FRACTURĂ DE INEL PELVIN}

Politraumatismul a fost definit conform noii definiții de la Berlin ca fiind asocierea a unui Injury Severity Score (ISS) $\geq 16$, tradus printr-un scor Abbreviated Injury Scale (AIS) $\geq 3$ pentru două sau mai multe regiuni ale corpului asociat cu una sau mai multe variabile suplimentare dintre următorii cinci parametri fiziologici: hipotensiune (tensiune arterială sistolică $\leq 90 \mathrm{mmHg}$ ), absența stării de conștiență (Glasgow Coma Scale $\leq 8$ ), acidoză (exces de baze $\leq-6.0$ ), tulburări de coagulare (timp parțial de tromboplastină $\geq 40 \mathrm{~s}$ sau international normalized ratio $\geq 1,4$ ) și vârsta ( $\geq 70$ ani) [7].

Fracturile de inel pelvin sunt leziuni relativ rare, cu o incidență raportată de aproximativ 2-8\% din totalul fracturilor, dar la pacienții politraumatizați această incidență poate crește până la peste $25 \%$ [8]. Riscul hemoragic face din fracturile de bazin una dintre cele mai serioase leziuni ale aparatului locomotor, având o mortalitate raportată ca fiind între 5 și 50\% în literatura de specialitate, această mortalitate depinzând atât de tipul de fractură, cât și de severitatea leziunilor asociate la nivel abdominal, toracic sau cerebral [9-11].

Cu toate că studiile recente au evidențiat o reducere progresivă în timp a mortalității pacienților politraumatizați cu fracturi complexe de bazin, aceasta rămâne inacceptabil de ridicată, aproximativ 18\% [11-12]. Din această cauză, definitorie pentru fractura complexă de bazin este asocierea cu leziuni de țesuturi moi, ca de exemplu fracturi deschise, inclusiv leziuni Morel-Lavalle, leziuni ale vaselor sangvine pelvine (inclusiv hematom retroperitoneal), leziuni urogenitale, leziuni de organe cavitare sau deficite neurologice cauzate în mod direct de fractura de bazin [9]. Această stagnare a mortalității poate fi atribuită unei limite biologice de supraviețuire (,trauma load“) sau, pe de altă parte, trebuie luată în considerare posibilitatea unui tratament inadecvat [13].

Pelvisul este un inel osteo-ligamentar format din osul sacral în posterior și cele două oase coxale formate din ilion, ischion și pubis. Rolul său este de 
a transfera greutatea corpului de la scheletul axial către membrele inferioare. Anatomia osoasă a inelului pelvin este în mod evident instabilă, astfel încât integritatea sa este dependentă de sistemele ligamentare care îl stabilizează. Bazinul posterior este stabilizat de ligamentele anterioare, intraarticulare și posterioare sacro-iliace la nivelul articulației sacro-iliace, precum și de ligamentele sacrospinoase și sacro-tuberoase ce leagă sacrul de ischion. Anterior, inelul pelvin este menținut de ligamentele simfizare. Aceste structuri asigură suport și pentru elementele vasculare, viscerale și neurologice care sunt conținute în sau traversează pelvisul, care sunt la risc în timpul producerii fracturii și atât timp cât aceasta nu este stabilizată. Ramurile principale ale arterei iliace trec imediat anterior de articulațiile sacro-iliace. Simfiza pubiană este imediat anterior de vezica urinară și uretră, în timp ce rectul se află imediat anterior față de sacru. Când forța necesară pentru fracturarea inelului pelvin este aplicată la acest nivel, aceste structuri sunt la risc [14].

În cazul fracturilor de bazin, hemoragia poate $\mathrm{fi}$ produsă din ramurile arterelor iliace, plexul venos presacrat sau din suprafața mare de os spongios fracturat, în general sângerarea fiind retroperitoneală. Din păcate, este greu de determinat proporțional ce procent din sângerare este arterial și cât este venos, cu toate că este acceptat ca principală sursă de sângerare plexul venos presacrat. în contrast cu hematoamele fracturare formate în cazul fracturilor de membre, hemoragia în fracturile de bazin urmează efectul de „coș de fum", deoarece, din cauza discontinuității din spațiul retroperitoneal, nu există efectul de autotamponadă, iar pacientul este la risc de exsangvinare $[9,15]$. Așadar, oprirea hemoragiei intrapelvine reprezintă cea mai importantă etapă în managementul de urgență al acestui tip de patologie, urmat de optimizarea capacității pacientului de a coagula vasele lezate $[13,16]$.

Valorile IL-6 rămân crescute pentru 5 sau mai multe zile la pacienții cu un ISS mare, iar valorile ridicate ale IL-6 au putut diferenția pacienții ce vor dezvolta ulterior insuficiența multiplă de organ [17]. În plus, studiile realizate de Pape HC, Giannoudis $\mathrm{P}$ și Krettek $\mathrm{C}$ arată că o concentrație sistemică a IL-6 ce depășește 800 pg/ml este predictibilă pentru dezvoltarea ulterioară a insuficienței de organ [18]. S-a demonstrat, de asemenea, că IL-6 este un marker adecvat pentru a cuantifica stresul operator suferit de pacient, Cruickshank și colab. raportând că procedurile chirurgicale elective pot duce la o creștere a valorii IL-6 din sângele venos direct, creștere proporțională cu amploarea și du- rata intervenției chirurgicale. Acest studiu a fost amplu criticat din cauza faptului că a comparat diverse procedee chirurgicale și astfel nu a luat în considerare o injurie chirurgicală comparabilă. Cu toate acestea, rezultatele au fost confirmate în momentul în care s-a măsurat impactul pe care îl are ostesinteza cu tijă centromedulară alezată a femurului ca operație standardizată, măsurători realizate la mai multe laboratoare independente, confirmând creșteri similare ale IL-6 în sângele venos după această procedură $[19,20]$. Un alt fenomen bine descris după traumatism este cel de priming leucocitar, studiile demonstrând că această activare este asociată cu o creștere a concentrației de IL-6 [21].

\section{CLASIFICAREA FRACTURILOR DE INEL PELVIN}

Cele mai utilizate două clasificări pentru fracturile de inel pelvin sunt cele descrise de Tile [22] și Young și Bourges [23]. În timp ce clasificarea Tile se axează în principal pe stabilitatea inelului pelvin posterior, Young și Burges aduc în prim-plan mecanismul traumatic urmat de efectele acestuia asupra inelului pelvin.

În clasificarea Tile, pelvisul este împărțit în arcul posterior (posterior de acetabul) și arcul anterior (anterior de acetabul), iar fracturile sunt împărțite în funcție de stabilitatea complexului sacro-iliac (arcul posterior). Prin urmare, această clasificare poate fi folosită pentru a ghida managementul fracturii de bazin. Inelul pelvin este stabil în fracturile Tile A. Fracturile Tile B sunt parțial stabile, prezentând o întrerupere incompletă a complexului sacro-iliac. În aceste fracturi, pelvisul este instabil rotațional, dar stabil în plan vertical. În fracturile Tile tip C, întreruperea completă a complexului ligamentar sacro-iliac provoacă instabilitate atât rotațională, cât și verticală. Fracturile pot fi clasificate suplimentar în funcție de traiectul fracturii și în funcție de instabilitatea uni- sau bilaterală (Tabelul 1) [14].

Bazându-se pe mecanismul de producere, Young și Burges au clasificat fracturile de inel pelvin în patru tipuri (Tabelul 1) [24].

Odată ajuns la Unitatea de Primiri Urgențe, pacientului politraumatizat trebuie să i se aplice protocolul Advanced Trauma Life Support (ATLS), cu monitorizarea imediată a căilor respiratorii (Airway), respirației (Breathing), Circulației, statusului neurologic (Disability) și a temperaturii corporale (Enviroment) [25]. Pentru pacienții cu fracturi de inel pelvin, este esențial să fie determinat modul în care fractura de bazin contribuie la he- 
TABEL 1. Clasificarea fracturilor de inel pelvin

\begin{tabular}{|c|l|l|l|}
\hline \multicolumn{2}{|c|}{ Clasificarea Tile } & \multicolumn{2}{c|}{ Clasificarea Young și Burges } \\
\hline Tip A & Stabilă (arcul posterior intact) & Compresie antero-posterioară (APC) \\
\hline A1 & Avulsie & APCI & Disjuncție pubiană <2,5 cm \\
\hline A2 & Fractură de aripă iliacă sau arc anterior & APC II & $\begin{array}{l}\text { Disjuncție pubiană }>2,5 \mathrm{~cm} \text { și lărgirea anterioară a articulației } \\
\text { sacro-iliace (ligamentele sacro-iliace posterioare indemne) }\end{array}$ \\
\hline A3 & Fractură transversă sacro-coccigiană & APC III & Leziune completă sacro-iliacă \\
\hline Tip B & Instabile rotațional & Compresie laterală (LC) \\
\hline B1 & $\begin{array}{l}\text { Rotație externă tip open-book cu centrul de } \\
\text { rotație la nivelul ligamentelor sacro-iliace } \\
\text { posterioare intacte }\end{array}$ & LCI & Compresie sacrată pe partea impactului \\
\hline B2 & Rotație internă prin compresie laterală & LC II & Fractura tip crescent (sripa iliacă) pe partea impactului \\
\hline B3 & Instabilitate rotațională bilateral & LC III & $\begin{array}{l}\text { LC I sau LC II pe partea impactului și APC pe partea } \\
\text { contralaterală }\end{array}$ \\
\hline Tip C & Instabile rotațional și vertical & Forfecare verticală (VS) \\
\hline C1 & Unilateral & VS & $\begin{array}{l}\text { Deplasare verticală anterior prin ramurile pubiene, iar } \\
\text { posterior prin aripa iliacă, articulația SI sau sacru }\end{array}$ \\
\hline C2 & Bilateral (Tip B pe o parte și C pe cealaltă) & Mecanism combinat (CMI) - de obicei LC+ VS \\
\hline C3 & Bilateral & \multicolumn{2}{|c|}{} \\
\hline
\end{tabular}

moragia ce poate amenința viața pacientului sau este o fractură simplă ce necesită doar tratament conservator. Hemoragia în traumatism este agravată și complicată de coagulopatia acută posttraumatică (ATC), descrisă ca o hipocoagulabilitate dezvoltată imediat în faza postinjurie ce produce hemoragie nonchirurgicală necontrolată [13].

\section{MANAGEMENTUL HEMORAGIEI}

Acesta ar trebui să fie dependent de caz și trebuie să fie adaptat particularităților pacientului, dar și condițiilor locale și experienței echipei. Opțiunile terapeutice pentru obținerea hemostazei la pacienții cu fracturi de inel pelvin includ: pelvic binder, fixare externă, fixare internă, hemostază chirurgicală directă, pelvic packing, angiografie și embolizare [26]. Hemoragia cu risc vital ca urmare a fracturilor de inel pelvin este posibilă din cauza sistemelor majore atât arteriale, cât și venoase de la nivel pelvin, a vascularizației bogate a oaselor de la acest nivel și a presiunii tisulare scăzute de la nivel retroperitoneal [27].

Hemoragia apare cel mai frecvent din cauza fracturilor instabile și a leziunilor plexurilor venoase presacral și prevezical. În contrast, leziunile arteriale cauzează hemoragie semnificativă la mai puțin de $20 \%$ dintre cazuri, dar este frecvent o cauză la pacienții cu instabilitate hemodinamică. La pacienții cu fractură de inel pelvin și hipotensiune arterială neresponsivă la măsurile de resuscitare, se decelează angiografic o leziune arterială în 73\% dintre cazuri [27]. Hemoragia masivă arterială poate avea ca sursă anterior artera pudendală (27\%), arterele obturatoare (16\%), iar posterior ar- tera gluteală superioară (25\%), latero-sacrată (23\%), gluteală inferioară (6\%) și arterele ilio-lombare (3\%) [28].

La toți pacienții cu fracturi de inel pelvin, hemoragia de origine venoasă și din suprafețele osoase fracturate va fi prezentă. Studii post-mortem [29] au demonstrat că hemoragia provine din lezarea vaselor pelvine mici și medii din vecinătatea oaselor spongioase. Această descoperire se corelează cu eșecul chirurgical al explorării și tentativelor de hemostază directă în prezența hemoragiei active când aceasta nu a putut fi identificată.

Înțelegerea acestei cauze de sângerare a dus la dezvoltarea unor metode de tratament care să nu afecteze formarea cheagului hemostatic. Imobilizarea în wrap sau binder sunt metode simple de stabilizare a inelului pelvin [30]. Pot fi folosite în prespital sau Unitatea de Primiri Urgențe în cazul în care se suspicionează o instabilitate de inel pelvin [31]. În prezența unei leziuni de tip open book, rotația internă a membrelor pelvine poate ajuta la stabilizarea condiției clinice a pacientului. Studii CT au demonstrat faptul că volumul pelvin nu se mărește semnificativ când este fracturat, motiv pentru care se consideră că aplicarea binderului reduce hemoragia prin stabilizarea fracturii mai degrabă decât prin efect de tamponadă produs prin reducerea volumului pelvin [32]. Fixarea externă a inelului pelvin poate fi folosită atât pentru stabilizarea fracturii, cât și pentru controlul hemoragiei. Aceste metode s-au dovedit eficace în controlul hemoragiei secundare leziunilor venoase, dar nu sunt eficiente în cazul sângerărilor cu sursă arterială. 


\section{EMBOLIZAREA ARTERIOGRAFICĂ}

S-a impus ca metodă de elecție în controlul hemoragiilor de cauză arterială în centrele pentru traumatisme. S-a dovedit a fi eficientă în controlul hemoragiilor de origine arterială cu o rată redusă a complicațiilor [33,34]. Această metodă necesită personal specializat și echipament special disponibil permanent cu alocarea resurselor necesare pentru a asigura transferul în siguranță al unui bolnav instabil hemodinamic în laboratorul de angiografie. Aceste resurse trebuie să includă obligatoriu suport anestezic, masă eritrocitară și mijloacele de a le administra rapid, monitorizarea continuă a pacientului și prezența echipei pentru traumatisme.

Decizia de a transfera un pacient instabil hemodinamic în laboratorul de angiografie sau în sala de operație nu este una ușoară, iar cel care ia această decizie trebuie să ia în considerare atât disponibilitatea resurselor necesare la unitatea spitalicească respectivă, cât și potențiala întârziere (uneori fără o sursă de sângerare ce poate fi embolizată) cauzată de efectuarea angiografiei, dată fiind disponibilitatea imediată a resurselor necesare unei laparotomii de urgență în orice unitate sanitară [14].

Pacienții care necesită intervenție chirurgicală de urgență pentru tratamentul instabilității hemodinamice trebuie tratați conform principiilor Damage Control Orthopedics (DCO). Procedeele chirurgicale prelungite și de amploare pot produce la pacienții politraumatizați, instabili hemodinamic, alterări ale cascadei coagulării, ale răspunsului imun și inflamație sistemică, ducând la MSOF [18]. Orice intervenție chirurgicală imediată trebuie să aibă ca obiectiv controlul hemostazei și trebuie să fie simplă și rapidă pentru a preîntâmpina apariția fenomenului de "second hit". Procedurile reconstructive complexe trebuie amânate până când pacientul este mai stabil din punct de vedere fiziologic.

Peste 5\% dintre bărbați și 3,5\% dintre femei prezintă leziuni urologice asociate fracturilor de bazin [35]. Cele mai frecvente leziuni sunt cele de vezică urinară, corpi cavernoși și uretră. Rupturile de vezică urinară au o incidență asemănătoare la bărbați și femei (aproximativ 3\%), dar leziunile uretrale sunt mult mai frecvente la bărbați $(1,54 \%)$ față de femei (0,15\%) [36].

\section{FIXAREA INTERNĂ A FRACTURILOR DE INEL PELVIN}

Din cauza complexității anatomice a pelvisului osos și a structurilor intrapelvine, fixarea internă a fracturilor de inel pelvin poate fi tehnic dificilă. Fi- xarea internă necesită, de cele mai multe ori, aborduri extensive pentru a permite reducerea și fixarea. Rate ale complicațiilor ce ajung până la $25 \%$ au fost publicate, majoritatea dintre ele din cauza abordului chirurgical mai degrabă decât din cauza traumatismului inițial $[37,38]$.

Fracturile de inel pelvin cu deplasare mare necesită frecvent reducere deschisă și fixare internă pentru restabilirea stabilității atât a componentei anterioare, cât și posterioare a inelului pelvin. Tratamentul conservator al fracturilor cu deplasare și instabile de bazin au rezultate nefavorabile pe termen lung [39]. Fixarea precoce folosind o combinație între fixarea internă și externă a devenit standardul de tratament, cu aportul echipei multidisciplinare pentru traumatisme ce îi permite pacientului să ajungă într-o stare de echilibru hemodinamic suficient de bună pentru a suporta stabilizarea ortopedică în 24-72 de ore de la traumatism [40].

Fixarea definitivă este determinată de gradul și tipul instabilității rezultate în urma fracturii de bazin. În absența instabilității verticale sau rotaționale (tipul A Tile), nu există indicație chirurgicală. În fracturile tip B Tile care produc instabilitate rotațională, dar nu și verticală, este în general suficientă fixarea inelului pelvin anterior, fie prin fixare externă, fie prin fixare internă [41]. Fracturile cu instabilitate verticală și rotațională (Tile tip C) necesită stabilizarea atât a inelului anterior, cât și posterior [42].

Stabilizarea inelului pelvin anterior se poate face prin reducere deschisă și fixare internă sau prin fixare externă.

\section{FIXAREA EXTERNĂ A INELULUI PELVIN ANTERIOR}

Poate fi folosită ca metodă de resuscitare, fixare provizorie, fixare definitivă sau pentru a suplimenta o fixare internă în cazul în care fixarea internă stabilă nu se poate obține [43]. Acest tip de fixare este în special utilă în cazul în care leziunile de țesuturi moi, inclusiv leziuni de vezică urinară sau intestinale, contraindică fixarea internă. Există două localizări posibile pentru introducerea fiselor pentru fixarea externă: antero-superior, la nivelul crestelor iliace, și antero-inferior, la nivelul osului dens supraacetabular, între spinele iliace anterosuperioară și antero-inferioară. Plasarea fiselor antero-superior are beneficiul inserării facile, cu un risc mai mic de lezare a nervului femuro-cutanat lateral. Trebuie luat în considerare faptul că anatomia crestelor iliace este caracteristică: acestea sunt înguste și curbe, iar densitatea osoasă la acest 
nivel este mai scăzută decât la nivel supraacetabular.

Fisele de la nivelul creste iliace erau inserate inițial perpendicular pe osul iliac, cu o direcție antero-superioară spre postero-inferior. Mai recent, au fost descrise fisele „subcristale" [44], care sunt inserate la nivelul spinelor iliace antero-superioare în osul subcondral paralel cu crestele iliace. Fisele inserate la nivelul crestei iliace au de obicei mai mult contact cu pielea abdominală, mai ales la pacienții obezi, acest lucru crescând probabilitatea de infecție perifisă și loosening [45].

Fisele poziționate antero-inferior oferă avantajul introducerii într-un os mai dens și al accesului la coloana anterioară [45]. Trebuie avută în considerare posibilitatea lezării nervului femuro-cutanat lateral, dar mai ales poziționarea intraarticulară a fisei. Din aceste motive, mulți chirurgi recomandă introducerea acestor fise prin abord „mini-open” și sub control fluoroscopic.

Punctul de maximă concentrare a stresului la nivelul unui fixator de bazin este la interfața os-fisă. Din acest motiv, dacă fisele nu sunt poziționate optim, pot deveni „loose”, ceea ce duce la pierderea integrității mecanice a fixatorului și la infecții perifisă. Forța necesară pentru extragerea fiselor este dictată de mai mulți factori, unii dependenți de fisă, ca diametrul și adâncimea filetului, dar și de factori operatori, ca plasarea exactă intracorticală sau adâncimea inserției [46]. Fisele acoperite cu hidroxiapatită au fost introduse pentru a mări rezistența la stres la interfața os-fisă, și a fost ulterior dovedit că reduc rata infecțiilor perifisă [47]. Principala complicație a fixatoarelor externe de bazin, ca de altfel a tuturor fixatoarelor externe, este infecția perifisă, rata infecției raportată în mai multe studii fiind de până la $30 \%$, inclusiv cazuri de osteomielită $[43,48]$.

O tehnică alternativă a fost introdusă folosind șuruburi pediculare spinale introduse la nivel suraacetabular și conectate printr-o bară poziționată printr-un tunel subcutanat, prin țesutul celular subcutanat, anterior de fascia musculară a mușchilor abdominali [49]. Acest „infix” are avantajul unor infecții perifisă mai puține [50,51], dar și faptul că plăgile operatorii sunt cusute peste șuruburile pediculare. Șuruburile inserate pot fi mai groase, fiind disponibile mărimi până la $10 \mathrm{~mm}$ diametru. Leziunea sau iritarea nervului cutanat femural lateral și osificările heterotopice sunt însă complicații frecvente [51].

Un alt dispozitiv folosit pentru fixarea externă a inelului pelvin este C-clamp, care este un fixator extern de urgență folosit pentru stabilizarea inelului pelvin posterior. Fisele se inseră la nivelul iliu- mului posterior și sunt comprimate cu ajutorul Cclamp-ului pentru a reduce fractura și a opri sângerarea, utilizarea lui fiind contraindicată în cazul fracturilor de os iliac și al fracturilor-luxație transiliace. Cele mai frecvente complicații descrise sunt leziuni ale pachetelor vasculonervoase fesiere și perforarea în pelvis [14].

\section{FIXAREA INTERNĂ A INELULUI PELVIN ANTERIOR}

Fracturile cu deplasare de inel pelvin anterior sau cele care necesită stabilizare definitivă sunt tratate prin reducere deschisă și fixare internă. Disjuncțiile de simfiză pubiană sunt tratate prin reducere și fixare cu o placă anterioară sau 2 plăci, una anterioară și una superioară, iar accesul se obține prin abord Stoppa pentru care se utilizează o incizie de tip Pfannenstiel. Disecția profundă pentru a aborda pubisul implică incizia liniei albe, cu toate că, de multe ori, inserțiile drepților abdominali sunt smulse în cazul disjuncțiilor de simfiză pubiană. Simfiza pubiană poate fi operată și prin abord ilio-inghinal. Plăcile utilizate pentru osteosinteza simfizei pubiene au un grad mare de deteriorare, din cauza faptului că, în cele din urmă, un grad de mobilitate la nivelul simfizei pubiene este restabilit, ceea ce duce la ruperea plăcii sau a șuruburilor. Deteriorarea montajului de osteosinteză este evidențiată radiologic în aproximativ $75 \%$ dintre cazuri [52], dar acest lucru nu este considerat clinic relevant $[52,53]$. Fracturile complexe de inel pelvin anterior pot necesita plăci mai lungi, un abord optim este obținut de obicei printr-un abord Stoppa, cu toate că uneori este necesară fereastra laterală din abordul ilio-inghinal. În momentul în care se continuă disecția mai lateral, trebuie avută în considerare prezența variabilă a corona mortis, o anastomoză vasculară între vasele obturatoare și iliace externe sau epigastrice inferioare. Localizată la o distanță variabilă față de simfiza pubiană, această structură este o sursă importantă de sângerare, iar dacă este lezată din greșeală hemostaza este dificil de realizat. Un studiu cadaveric a identificat această anastomoză la $83 \%$ dintre subiecți la o distanță între 40 și 93 mm față de simfiza pubiană [54].

\section{STABILIZAREA INELULUI PELVIN POSTERIOR}

Leziunile inelului pelvin posterior includ disjuncțiile sacro-iliace, fracturile sacrate și fracturile iliace. Morbiditatea asociată abordurilor chirurgicale extensive pentru pelvisul posterior a dus la 
explorarea unor metode alternative de tratament. Șuruburile iliosacrate introduse percutanat pentru fracturile sacrate și disjuncțiile sacro-iliace s-au dovedit a fi o alternativă la reducerea și fixarea deschise, cu rate de sângerare și infecție net inferioare $[55,56]$. Această tehnică implică reducerea închisă a fracturilor de inel pelvin posterior și fixarea folosind un șurub canulat trecut prin baza aripii iliace, aripa sacrată și corpul sacrului ghidat de fluoroscopie intraoperatorie în incidentele inlet, outlet și laterale. Complexitatea și variabilitatea anatomiei inelului pelvin posterior trebuie recunoscute înainte de planning-ul și inserția șuruburilor percutanat. Studiul reconstrucțiilor 3D după imaginile CT au demonstrat dimensiunile pediculului sacrat, care reprezintă cea mai îngustă parte a traiectului sigur pentru aceste șuruburi, cu o lățime medie de 15,6 mm (11,6-20,2 mm) [57,58]. Această dimensiune este semnificativ mai scăzută în cazul prezenței unui deficit de reducere [59]. O eroare de doar 4 grade deviație a unghiului șurubului, a fost demonstrat că este suficientă pentru a perfora găurile de conjugare sacrate sau cortexul anterior [60]. Poziționarea greșită a șuruburilor și calusul vicios sunt complicații raportate frecvent, în unele cazuri fiind descrise și complicații neurologice [61].

În unele tipuri de fractură de inel pelvin posterior poate fi imposibil de obținut reducerea închisă. Reducerea deschisă a fracturilor sacrate poate fi obținută printr-o incizie paramediană centrată pe sacru și abord transgluteal cu pacientul poziționt în decubit ventral. Opțiunile de fixare includ șuruburi ilio-sacrate percutanate, plăci posterioare sau principiul benzii de tensiune cu o placă sau „internal fixtor" la nivelul spinelor iliace posterosuperioare. Ca în cazul tuturor plăgilor în această regiune, probabilitatea de dehiscență și infecție este mare [62].

Progresele în fixarea fracturilor de inel pelvin și în managementul perioperator au determinat

multe centre pentru traumatisme să adopte un protocol mai agresiv pentru tratamentul acestor leziuni; cu toate acestea, această atitudine rămâne controversată. în trecut, majoritatea fracturilor de inel pelvin au fost tratate conservator, dar există tot mai multe dovezi care leagă managementul conservator al fracturilor cu deplasare de aripă sacrată și inel pelvin în general de acest rezultat funcțional final nefavorabil $[41,63]$.

Rezultatele funcționale deficitare au fost legate de deplasarea fracturii și apariția calusului vicios. Mai multe studii au demonstrat persistența durerii și impotența funcțională relativă la pacienții cu deformare reziduală a inelului pelvin posterior peste $1 \mathrm{~cm}[41,63]$.

S-a demonstrat că tratamentul chirurgical atât al fracturilor de inel pelvin anterior, cât și al celor de inel pelvin posterior are rezultate funcționale mai bune decât tratamentul conservator. O lucrare amplă despre managementul fracturilor de bazin [41] a constatat că tratamentul chirurgical al fracturilor de inel pelvin duce la o rată superioară de consolidare și o reducere mai bună a fracturii decât în cazul tratamentului conservator. Tulburările de mers au fost, de asemenea, mai des întâlnite în cazul tratamentului conservator.

\section{CONCLUZII}

Fracturile de bazin produse prin mecanism de înaltă energie sunt o problemă serioasă de tratament. Prioritățile tratamentului inițial sunt reprezentate de identificarea și tratamentul leziunilor ce pun în pericol viața pacientului, obiectivul stabilizării definitive fiind corectarea diformității, restaurarea funcției și reducerea ratei complicațiilor.

\section{Mențiune}

Toți autorii au contribuit în mod egal la realizarea acestui articol.

\section{Conflict of interest: none declared} Financial support: none declared

\section{BIBLIOGRAFIE}

1. Guisasola MC, Ortiz A, Chana A et al. Early inflammatory response in polytraumatized patients: Cytokines and heat shock proteins. A pilot study. Orthopaedics \& Traumatology: Surgery \& Research, 2015; 101:607-611

2. Sapan $H$, Paturusi I, Islam A et al. Interleukin-6 and interleukin-10 plasma levels and mRNA expression in polytrauma patients. Chinese Journal of Traumatology, 2017; 20:318-322.

3. Cuschieri J, Bulger E, Schaeffer V et al. Inflammation and the Host Response to
Injury Collaborative Research Program. Early elevation in random plasma IL-6 after severe injury is associated with development of organ failure. Shock, 2010; 34(4):346-351.

4. Tilg H, Dinarello $C$, Mier J. IL-6 and APPs: Anti-inflammatory and immunosuppressive mediators. Immunology Today, 1997; 18(9):428-432.

5. Foex B, Lamb W, Roberts T et al. Early cytokine response to multiple injury. Injury, 1993; 24(6):373-376.
6. Tschoeke SK, Ertel W. Immunoparalysis after multiple trauma. Injury, 2007; 38(12):1346-1357

7. Rau C, Wu S, Kuo P et al. Polytrauma Defined by the New Berlin Definition: A Validation Test Based on Propensity-Score Matching Approach. Int J Environ Res Public Health, 2017; 1045(14).

8. Balogh Z, King K, Mackay P et al. The epidemiology of pelvic ring fractures: $A$ population-based study. Journal of Trauma, 2007; 63:1066-1073. 
9. Bosch U, Pohlemann T, Haas $\mathrm{N}$ et al. Classification and management of complex pelvic trauma. Unfallchirurgie, 1992; 95:189-196.

10. Hauschild O, Strohm P, Culemann U et al. Mortality in patients with pelvic fractures: Results from the German pelvic injury register. The Journal of Trauma: Injury, Infection, and Critical Care, 2008; 64(2), 449-455.

11. Pohlemann T, Stengel D, Tosounidis $G$ et al. Survival trends and predictors of mortality in severe pelvic trauma: Estimates from the German Pelvic Trauma Registry Initiative. Injury, 2011; 42:997-1002.

12. Burkhardt M, Nienaber U, Pizanis A et al. Acute management and outcome of multiple trauma patients with pelvic disruptions. Critical Care, 2012; 16:R163.

13. Burkhardt M, Kristen A, Culemann U et al. Pelvic fracture in multiple trauma: Are we still up-to-date with massive fluid resuscitation? Injury, 2016; 45:70-75.

14. Wong J, Bucknill A. Fractures of the pelvic ring. International Journal of the Care of the Injured, 2017; 48:795-802.

15. Pohlemann T, Culemann U, Gansslen A et al. Severe pelvic injury with pelvic mass hemorrhage: Determining severity of hemorrhage and clinical experience with emergency stabilization. Unfallchirurgie, 1996; 99:734-743.

16. Dyer GSM, Vrahas MS. Review of the pathophysiology and acute management of haemorrhage in pelvic fracture. Injury, 2006; 37:602-613.

17. Partrick $D$, Moore F, Moore E. The inflammatory profile of IL-6, IL-8, and soluble intercellular adhesion molecule-1 in post-injury. American Journal of Surgery, 1996; 172:425-429.

18. Pape H, Giannoudis P, Krettek C. The timing of fracture treatment in polytrauma patients: Relevance of damage control orthopedic surgery. The American Journal of Surgery, 2002; 183(6):622-629.

19. Giannoudis P, Smith R, Bellamy M et al. Stimulation of the inflammatory system by reamed and unreamed nailing of femoral fractures - an analysis of the second hit. Journal of Bone And Joint Surgery, 1999; 81:356-361.

20. Pape H, Schmidt R, Rice J. Biochemical changes following trauma and skeletal surgery of the lower extremity quantification ofthe operative burden. Critical Care Medicine, 2000; 28:3441-3448.

21. Ogura $\mathrm{H}$, Tanaka $\mathrm{H}$, Koh T et al. Priming, second hit priming, and apoptosis in leukocytes from trauma patients. Journal of Trauma and Acute Care Surg, 1999; 6:774-783

22. Tile M. Pelvic ring fractures: Should they be fixed? The Bone \& Joint Journal, 1998; 70:1-12.

23. Young J, Burgess A, Brumback R et al. Pelvic fractures: Value of plain radiography in early assessment and management. Radiology, 1986; 160:445-451.
24. Trikha V, Gupta H. Current management of pelvic fractures. J Orthop Trauma, 2011; 2(1):12-18.

25. American College of Surgeons, Advanced Trauma Life Support for Doctors (ATLS) Instructor Course Manual, Chicago, 1997.

26. Giannoudis P, Pape H. Damage control orthopaedics in unstable pelvic ring injuries. Injury, 2004; 35:671-677.

27. Guthrie H, Owens R, Bircher M. Fractures of the pelvis. J Bone Joint Surg, 2010; 92:1481-1488.

28. Heetveld M, Harris I, Schlaphoff G et al. Guidelines for the management of haemodynamically unstable pelvic fracture patients. ANZ Journal of Surgery, 2004; 74:520-529.

29. Huittinen V, Slätis P. Postmortem angiography and dissection of the hypogastric artery in pelvic fractures. Surgery, 1973; 73(3):454-462.

30. Flint LJ, Brown A, Richardson J et al. Definitive control of bleeding from severe pelvic fractures. Ann Surg, 1979; 186(6):709-716.

31. Bottlang M, Krieg J. Introducing the pelvic sling. Pelvic fracture stabilization made simple. Journal of Emergency Medical Services, 2003; 28(9):84-93.

32. Stover M, Summers H, Ghanayem A et al. Three-dimensional analysis of pelvic volume in an unstable pelvic fracture. The Journal of Trauma and Acute Care Surg, 2006; 61(4):905-908.

33. Moreno C, Moore E, Rosenberger A et al. Hemorrhage associated with major pelvic fracture: A multispecialty challenge. The Journal of Trauma and Acute Care Surg, 1986; 26:987-994.

34. Morozumi J, Homma H, Ohta S et al. Impact of mobile angiography in the emergency department for controlling pelvic fracture hemorrhage with hemodynamic instability. The Journal of Trauma and Acute Care Surg, 2010; 68(1):90-95.

35. Bjurlin M, Fantus R, Mellett M et al. Genitourinary injuries in pelvic fracture morbidity and mortality using the National Trauma Data Bank. The Journal of Trauma and Acute Care Surg, 2009; 67(5):10331039.

36. Hadjizacharia P, Inaba K, Teixeira P et al. Evaluation of immediate endoscopic realignment as a treatment modality for traumatic urethral injuries. The Journal of Trauma and Acute Care Surg, 2008; 64(6):1443-1450.

37. Kellam J, McMurtry R, Paley D et al. The unstable pelvic fracture. Operative treatment. Orthop Clinics North Am. 1987; 18(1):25-41.

38. Routt JM, Simonian P, Swiontkowski M. Stabilization of pelvic ring disruptions. Orthop Clin North Am., 1997; 28(3):369388.

39. Flint L, Cryer H. Pelvic fracture: The last 50 years. The Journal of Trauma and Acute Care Surg, 2010, 69(3):483-488.

40. Goldstein A, Phillips T, Sclafani S et al. Early open reduction and internal fixation of the disrupted pelvic ring. The Journal of Trauma and Acute Care Surg. 1986; 26(4):325-333.

41. Papakostidis C, Kanakaris N, Kontakis G et al. Pelvic ring disruptions: Treatment modalities and analysis of outcomes. Int Orthop. 2009; 33(2):329-338.

42. van den Bosch E, van Zwienen C, Hoek van Dijke $G$ et al. The Journal of Trauma and Acute Care Surg. 2003; 55(5):962-965.

43. Tucker M, Nork S, Simonian P et al. Simple anterior pelvic external fixation. The Journal of Trauma and Acute Care Surg, 2000; 49(6):989-994.

44. Solomon L, Pohl A, Sukthankar A et al. The subcristal pelvic external fixator: Technique, results, and rationale. J Orthop Trauma, 2009; 23(5):365-369.

45. Kim W, Hearn T, Seleem O et al. Effect of pin location on stability of pelvic external fixation. Clin Orthop Relat Res. 1999; 361:237-244.

46. Liu J, Lai K, Chou Y. Strength of the pin-bone interface of external fixation pins in the iliac crest. A biomechanical study. Clin Orthop Relat Res. 1995; 310:237-244.

47. Moroni A, Aspenberg B, Toksvig-Larsen S et al. Clin Orthop Relat Res. 1998; 346:171-177.

48. Majeed S. External fixation of the injured pelvis. The functional outcome. J Bone Joint Surg. 1990; 72(4):612-614.

49. Merriman DJ, Ricci W, McAndrew C et al. Is application of an internal anterior pelvic fixator anatomically feasible? Clin Orthop Relat Res. 2012; 470(8):2111-2115.

50. Hiesterman T, Hill B, Cole P. Surgical technique - A percutaneous method of subcutaneous fixation for the anterior pelvic ring: The pelvic bridge. Clin Orthop Relat Res. 2012; 470(8):2116-2123.

51. Vaidya R, Kubiak E, Bergin $P$ et al. Complications of anterior subcutaneous internal fixation for unstable pelvis fractures: A multicenter study. Clin Orthop Relat Res. 2012; 470(8):2124-2131.

52. Collinge C, Archdeacon M, Dulaney-Cripe E et al. Radiographic changes of implant failure after plating for pubic symphysis diastasis: An underappreciated reality? Clin Orthop Relat Res. 2012; 470(8):2148-2153.

53. Morris S, Loveridge J, Smart D et al. Is fixation failure after plate fixation of the symphysis pubis clinically important? Clin Orthop Relat Res. 2012; 470(8):2154-2160.

54. Darmanis S, Lewis A, Mansoor A et al. Corona mortis: An anatomical study with clinical implications in approaches to the pelvis and acetabulum. Clinical Anatomy, 2007; 20(4); 433-439.

55. Routt MJ, Kregor P, Simonian $P$ et al. Early results of percutaneous iliosacral screws placed with the patient in the supine position. J Orthop Trauma, 1995; 9:207-214.

56. Shuler T, Boone D, Gruen G et al. Percutaneous iliosacral screw fixation: Early treatment for unstable posterior pelvic 
ring disruptions. Journal of Trauma and Acute Care Surg, 1995; 38(3):453-458.

57. Noojin FK, Malkani A, Haikal L et al. Cross-sectional geometry of the sacral ala for safe insertion of iliosacral lag screws: A computed tomography model. J Orthop Trauma, 2000; 14(1):31-35.

58. Bucknill A, Yew J, Clifford J et al. Percutaneous pelvic screw placement in pelvic trauma using computer navigation. J Bone Joint Surg, 2012; 196.

59. Reilly M, Bono C, Litkouhi B et al. The effect of sacral fracture malreduction on the safe placement of iliosacral screws. J Orthop Trauma 2006; 20:37-43.

60. Templeman D, Schmidt A, Freese J et al. Proximity of iliosacral screws to neurovascular structures after internal fixation. Clin Orthop Relat Res. 1996; 329:194-198.

61. Keating J, Werier J, Blachut P et al. Early fixation of the vertically unstable pelvis: The role of iliosacral screw fixation of the posterior lesion. J Orthop Trauma.,1999; 13(2):107-113. .
62. Hsu J, Bear R, Dickson K. Open reduction internal fixation of displaced sacral fractures: Technique and results. Orthopedics, 2010; 33(10).

63. McLaren AC, Rorabeck C, Halpenny J. Long-term pain and disability in relation to residual deformity after displaced pelvic ring fractures. Canadian Journal of Surgery, 1990; 33(6):492-494. 